\title{
Evaluation of 20 Pediatric Cases Diagnosed with Measles in Diyarbakır Children's Hospital in 2019
}

\author{
2019 Yılında Diyarbakır Çocuk Hastanesinde Kızamık Tanısı Alan \\ 20 çocuk Olgunun İdelenmesi
}

\author{
Sevliya Öcal Demir(iD), Özlem Aksoy²(iD), Gülnaz Kubat(iD), Servinaz Meşeli²(ID), Behice Yukuş²(ID) \\ ${ }^{1}$ Department of Pediatrics, Istanbul Medeniyet University, Goztepe Training and Research Hospital, Istanbul, Turkey \\ ${ }^{2}$ Clinic of Pediatrics, Diyarbakir Child Health and Diseases, Diyarbakır, Turkey \\ ${ }^{3}$ Directorate of Public Health Services, Provincial Health Directorate, Diyarbakır, Turkey
}

Cite this article as: Öcal Demir S, Aksoy Ö, Kubat G, Meşeli S, Yukuş B. Evaluation of 20 pediatric cases diagnosed with measles in Diyarbakır Children's Hospital in 2019. J Pediatr Inf 2020;14(3):e123-e128.

\section{Abstract}

Objective: Measles is a highly contagious viral disease which can cause serious complications and be prevented with vaccination. In this study, we evaluated the demographic, clinical and laboratory findings of 20 children diagnosed with measles in order to use these data to determine strategies for early detection, control and prevention of measles outbreaks.

Material and Methods: A total of 20 patients followed up with the diagnosis of measles in Diyarbakır Children's Hospital between $2^{\text {nd }}$ April 2019 to 9th July 2019 were evaluated retrospectively. Data about patients' demographic characteristics, clinical and laboratory findings, treatments and complications were obtained from medical records.

Results: The age range of the patients was 5-214 months; median age was 11 months (8-27). Of the cases, 15 (75\%) were males and 5 (25\%) were females. Five $(25 \%)$ cases had a history of contact with measles patients. Nineteen cases had no measles vaccination and 1 case had a single dose of measles vaccination. The most common clinical signs and symptoms were high fever (100\%), catarrhal symptom and cough (95\%), conjunctivitis (55\%), maculopapular rash (45\%), and Koplik's spots (30\%). Laboratory tests revealed lymphopenia in 10 (50\%) cases, leukopenia in $5(25 \%)$ cases, and thrombocytopenia in $1(5 \%)$ case. C-reactive protein was high in 8 (40\%) cases, and the mean value was $28.75 \mathrm{mg} / \mathrm{dL}$ (9.9539.3). Complications were bronchopneumonia in three cases, febrile convulsion in one case, diarrhea and acute dehydration in one case. All cases were discharged without sequels.

Conclusion: Measles is a highly contagious disease; prevention of outbreaks is possible by keeping vaccination rates of the population high.
Öz

Giriş: Kızamık ciddi komplikasyonlarla seyredebilen aşı ile önlenebilen oldukça bulaşıcı viral enfeksiyon hastalığıdır. Bu çalışmada kızamık salgınlarının erken saptanması, kontrolü ve önlenmesi için strateji belirlenmesinde kullanılabilecek veri elde etmek amacıyla kızamık tanısı alan 20 çocuk olgunun demografik, klinik ve laboratuvar bulguları irdelendi.

Gereç ve Yöntemler: 2 Nisan-9 Temmuz 2019 tarihleri arasında Diyarbakır Çocuk Hastanesine başvuran, kızamık tanısı ile yatırılarak izlenen 20 çocuk olgu retrospektif olarak incelendi. Olguların demografik özellikleri, klinik ve laboratuvar bulguları, aldığı tedaviler ve gelişen komplikasyonları ile ilgili veriler tıbbi kayıtlardan elde edildi.

Bulgular: Hastaların yaş dağılımı 5-214 ay arasında, medyan yaş 11 ay (8-27), 15 (\%75)'i erkek, 5 (\%25)'i kız idi. Beş (\%25) olguda temas hikayesi vardı. On dokuz olgu kızamık aşısı olmamış, bir olgunun tek doz kızamık aşılaması mevcuttu. Başvuruda ön planda olan klinik belirti ve bulgular yüksek ateş (\%100), nezle ve öksürük (\%95), konjunktivit (\%55), makülopapüler döküntü (\%45) ve Koplik lekeleri (\%30) idi. Laboratuvar tetkiklerinde 10 (\%50)'unda lenfopeni, 5 (\%25)'inde lökopeni, 1 (\%5)'inde trombositopeni tespit edildi. C-reaktif protein 8 (\%40) olguda yüksek medyan 28.75 mg/dL (9.95-39.3) idi. Gelişen komplikasyonlar üç olguda bronkopnömoni, birinde febril konvülziyon, birinde ishal ve akut dehidratasyon idi, hepsi şifa ile taburcu edildi.

Sonuç: Kızamık, bulaşıcılığı oldukça yüksek bir enfeksiyon hastalığıdır, salgınlarının önlenmesi aşılama oranlarının yüksek tutulması ile mümkündür. Ek olarak salgın dönemlerinde kızamığın prodromal evredeki semptomlarını gösteren bir yaşından küçük duyarlı çocuklara şüphe

Correspondence Address/Yazışma Adresi

Sevliya Öcal Demir

İstanbul Medeniyet Üniversitesi,

Göztepe Eğitim ve Araştırma Hastanesi,

Çocuk Sağlığı ve Hastalıkları Anabilim Dalı,

İstanbul-Türkiye

E-mail: sevliyademir@gmail.com 
In addition, during outbreaks of measles suspicious approach to children under 12 months who show prodromal symptoms of measles will provide early diagnosis. Early diagnosis will make possible early isolation, rapid management of their contacts, and so will significantly reduce outbreak.

Keywords: Measles, epidemic, isolation, maculopapular, rash, child

\section{Introduction}

Measles is a highly contagious viral infection seen worldwide. The agent of the disease is an RNA virus from the morbillivirus group of the paramyxoviridae family. Infecting only humans, this virus becomes an epidemic in the end of winter and spring months since it can stay alive in low temperatures. Disease development rate in susceptible individuals after contact with the virus is $90 \%$. Its period of contagiousness is accepted as 4 days before and 4 days after the start of rash (1). The incubation period of the disease is between 6 and 21 days, mean 13 days (2). Prodromal period is characterized with high fever, catarrh, cough, and conjunctivitis, and maculopapular rash developing afterwards. The rash begins from the hairy skin and face with an inclination to merge and spreads to the extremities but does not involve the palms and plantar and heals with hyperpigmentation after approximately 5-6 days. Lifelong immunization remains after having measles.

Vaccination is the most effective method of protection from measles. World Health Organization (WHO) recommends community immunization to increase up to $95 \%$ for the control of the disease, prevention of epidemics, and elimination of the disease. Vaccination rate, which was $98 \%$ in 2016 in our country, dropped to $96 \%$ in the years 2017 and 2018. Vaccination rates in Southeastern Anatolia, where the province Diyarbakir is also located, is again $96 \%$ (3). According to the data of the Ministry of Health, the number of cases in the years 2013, 2014, 2015, 2016, 2017 , and 2018 was $7405,565,342,9,84$, and 716 , respectively. Along with the fact that data on the year 2019 has not been published yet, it is believed that there is a significant rise in the number of cases. Measles is still an endemic disease in Turkey and continues to cause epidemics once in 3-4 years. ile yaklaşmak erken tanıyı sağlayacaktır, erken tanı ve temaslıların hızlı yönetimi, izolasyon önlemlerine sıkı uyulması bulaşıcılığı önemli ölçüde azaltacaktır.

Anahtar Kelimeler: Kızamık, salgın, izolasyon, makülopapüler, döküntü, çocuk

A significant increase in the number of cases in 2019 in our region and the fact that cases had received diagnosis as of April 2019 caught our attention, and with this study, it was aimed to determine factors that could be helpful in the prevention or control of the epidemic by examining the demographic, clinical, and laboratory characteristics of the patients diagnosed with measles.

\section{Materials and Methods}

The study included hospitalized patients that presented to the Diyarbakir Children's Hospital between April 2-July 9, 2019 and fit the confirmed case description of the Measles, Rubella and Congenital Rubella Syndrome Surveillance (MRCS) Permanent Memorandum of the Ministry of Health (Table 1) (4). Data were obtained from patient files, medical records, and Ministry of Health Measles/Rubella Examination Form. Demographics of the patients, clinical and laboratory findings, the treatments they had received, and the complication that had developed were noted on the form prepared for the study. Laboratory tests were evaluated with age-appropriate reference range.

SPSS 22.0 package program was used for analysis. Continuous variables were presented as mean \pm standard deviation or median \pm interquartile range; and categorical variables were presented as number of cases and percentage (\%).

The study was approved by Health Sciences University, Diyarbakir Gazi Yasargil Training and Resarch Hospital Ethics Board with date/number: 4.7.2019/325.

\section{Results}

A total of 20 cases were included into the study. Fifteen (75\%) were males and 5 (25\%) were females. Age range

Table 1. Case identifications and classifications of Measles, Rubella and Congenital Rubella Syndrome Surveillance (MRCS) Permanent Memorandum of the Ministry of Health (4)

\footnotetext{
Suspected Case: Any disease presenting with maculopapular rash.

Probable Measles Case (Clinical Case): Case compatible with clinical description'.

Definitive Measles Case:

a. Laboratory-confirmed Case: Probable Case confirmed with one of the criteria ${ }^{2}$ needed for diagnosis or if vaccinated recently, case with an epidemiological relation to the laboratory-confirmed case.

b. Epidemiology-related Case: Probable Case with an epidemiology-related relation (time and place in terms of contact and incubation-contact 7-18 days prior to the start of symptoms) to a laboratory-confirmed case

Not a Case: Negative laboratory tests in an individual with symptoms and signs compatible with the clinical definition of measles or case with an epidemiologic relation to a case confirmed by the laboratory of not having measles (for instance, (örn: roseola infantum, erythema infection, and etc)

'Fever higher than $38^{\circ} \mathrm{C}$ and maculopapular rash and cough or running nose or disease characterized by conjunctivitis.

'Detection of measles-specific IgM antibody or measles virus isolation or detection of measles viral RNA with RT-PCR or significant increase (at least 4 times) in measlesspecific lgG antibody titer in serum samples taken at 2-4 weeks interval.
} 


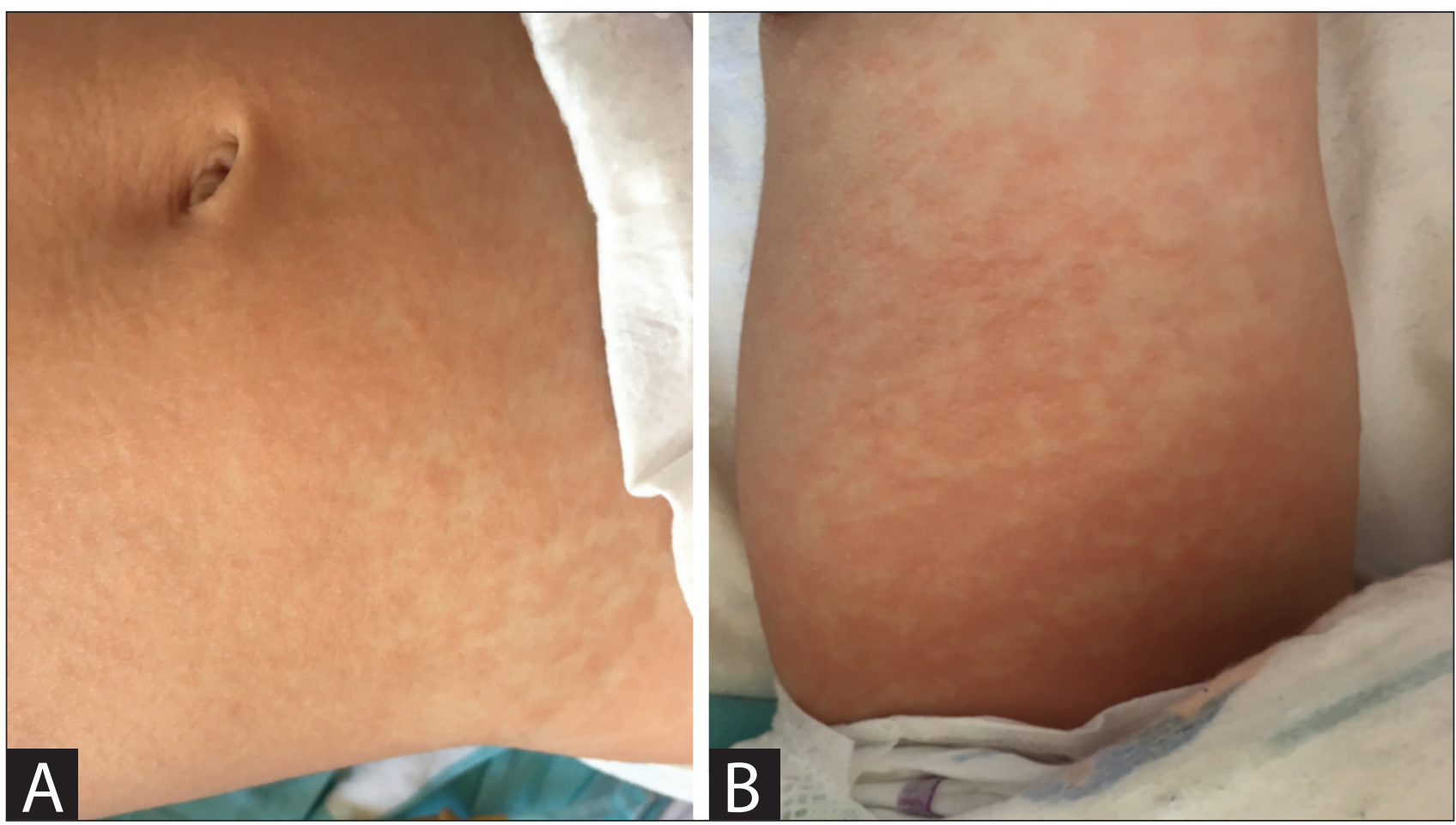

Figure 1. Maculopapular rashes in the abdomen region $(A)$ and leg $(B)$ of the case with measles.

was 5-214 months; median age was 11 months (range: 8-27 months). Thirteen (65\%) of the cases were younger than 12 months and had not received their measles vaccination yet, $6(30 \%)$ of the patients were older than 12 months and had not received any of the age-appropriate vaccinations, and 1 (5\%) patient was older than 12 months and had the single

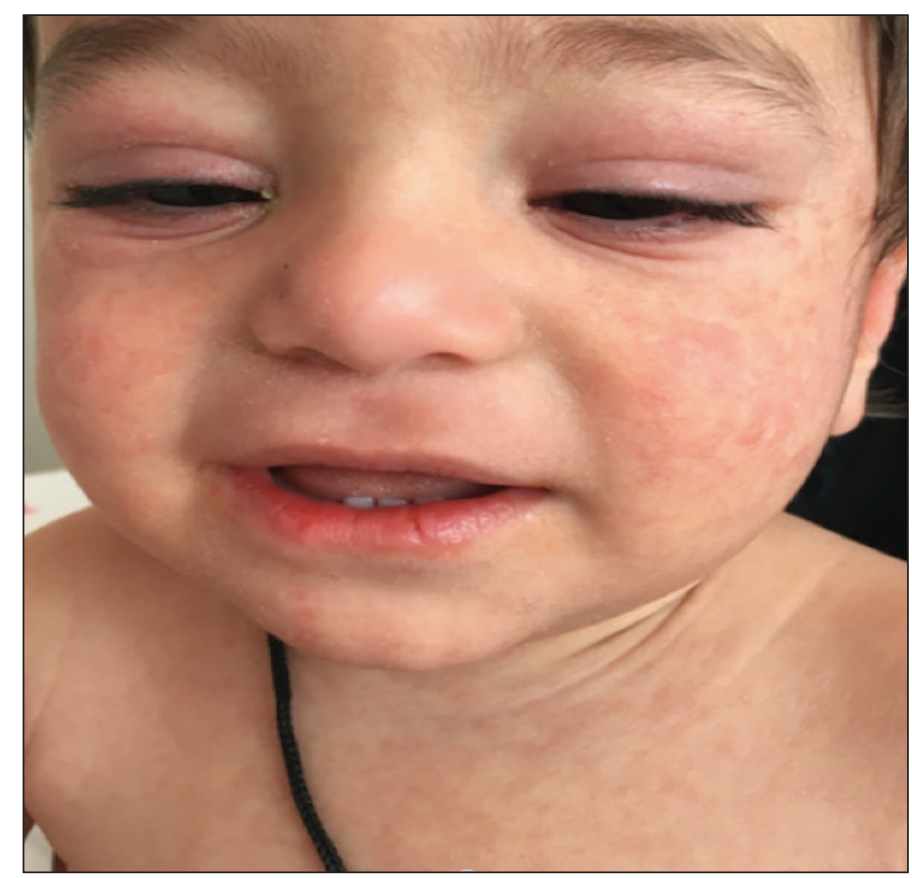

Figure 2. Conjunctivitis in the case with measles, transverse marginal lines on the lower eye lids (Stimson sign). dose of measles vaccination. There were five cases who got into contact with measles patients, of whom 4 got into contact at hospital. Symptoms and signs of the cases at the time of presentation were fever (100\%), catarrh and cough (95\%), conjunctivitis (55\%), maculopapular rash (45\%), and Koplik's spots (30\%) (Figure 1, 2). Eleven cases without any rashes on presentation experienced maculopapular rashes during follow-up. Table 2 summarizes the symptoms and clinical findings of the cases on presentation.

Laboratory tests revealed lymphopenia in 10 (50\%) cases, leucopenia in 5 (25\%) cases, and thrombocytopenia in 1 (5\%) case. While aspartate aminotranspherase (AST), alanine

Table 2. Clinical findings and symptoms of the cases on presentation

\begin{tabular}{|l|c|}
\hline Symptoms & $\begin{array}{c}\text { Number of patients } \\
\mathbf{n}(\%)\end{array}$ \\
\hline Fever & $20(\% 100)$ \\
\hline Catarrhal symptom/cough/running nose/catarrh & $19(\% 95)$ \\
\hline Lachrymation/photophobia & $11(\% 55)$ \\
\hline Diarrjea & $5(\% 25)$ \\
\hline Findings & \\
\hline Makulopapular rash & $9(\% 45)$ \\
\hline Koplik's spots & $6(\% 30)$ \\
\hline Conjunctivitis & $11(\% 55)$ \\
\hline Lymphadenopathy & $3(\% 15)$ \\
\hline
\end{tabular}


Table 3. Laboratory values of the cases

\begin{tabular}{|l|c|c|}
\hline Hemogram & Mean value & Min-max value \\
\hline Leucocyte $\left(\mathrm{mm}^{3}\right)$ & $8.26 \pm 3.64$ & $3.22-14.89$ \\
\hline Neutrophil $\left(\mathrm{mm}^{3}\right)$ & $3.34 \pm 1.96$ & $1.16-6.95$ \\
\hline Lymphocyte $\left(\mathrm{mm}^{3}\right)$ & $4.23 \pm 3.02$ & $0.77-11.9$ \\
\hline Hemoglobin $(\mathrm{g} / \mathrm{dL})$ & $11.38 \pm 2.03$ & $7.4-16.3$ \\
\hline Thrombocyte $\left(\mathrm{mm}^{3}\right)$ & $315.22 \pm 135.62$ & $120-642$ \\
\hline Biochemical values & Mean value & Min-max value \\
\hline Alanine aminotranspherase $(\mathrm{U} / \mathrm{L})$ & $23.58 \pm 10.15$ & $10-43$ \\
\hline Aspartate aminotranspherase $(\mathrm{U} / \mathrm{L})$ & $43.16 \pm 11.38$ & $17-67$ \\
\hline Lactate dehydrogenase $(\mathrm{U} / \mathrm{L})$ & $411 \pm 86.39$ & $347-552$ \\
\hline Creatinine $(\mathrm{mg} / \mathrm{dL})$ & $0.46 \pm 0.11$ & $0.4-0.8$ \\
\hline C-reactive $p r o t e i n(\mathrm{mg} / \mathrm{dL})$ & $28.75 *$ & $2.3-142$ \\
\hline$*$ Median & & \\
\hline
\end{tabular}

aminotransferase (ALT), blood urea nitrogen (BUN), and lactate dehydrogenase (LDH) were found normal in biochemical test, creatinine level in one patient with dehydratation was found at the borderline with $0.8 \mathrm{mg} / \mathrm{dL}$. C-reactive protein (CRP) (reference value $<5 \mathrm{mg} / \mathrm{dL}$ ) was found high (40\%) in 8 patients, and the median value was $28.75 \mathrm{mg} / \mathrm{dL}$ (range: 9.95-39.3). Erythrocyte sedimentation rate (ESR) was tested in two patients and found as $37 \mathrm{~mm} /$ hour and $9 \mathrm{~mm} / \mathrm{hour}$. In blood samples sent to Diyarbakir Provincial Public Health Laboratory for measles, measles IgM was found positive in all patients with the method Enzyme-Linked Immunosorbent Assay (ELISA). Laboratory values of the patients are summarized in Table 3.

All cases included into the study were inpatients of the Pediatric Clinic, whose tests and treatments were arranged as necessary. The first preliminary diagnosis of hospitalization was measles in 9 (45\%), bronchiolitis in 7 (35\%), and fever without a source in $4(20 \%)$ patients. Kawasaki disease was simultaneously considered in two cases with fever without a source. Three cases developed bronchopneumonia, one developed diarrhea and dehydratation and one developed febrile convulsion, all discharged with full recovery.

\section{Discussion}

Age range of the cases in our study was 5-214 months, and median age was 11 months (range: 8-27 months). In a 2012 study of Metin et al. conducted in Ankara with 44 measles cases, age range was found as 4-191 months and median age as 58.6 \pm 59.5 months (5). During the 2013-2014 epidemic in Istanbul, Türkkan et al. found the age range of 20 cases as 7-196 months and median age as $63.8 \pm 44$ months (6). In comparison to both studies, the median age determined in our study was younger, which was due to the fact that $65 \%$ of our cases consisted of those under the age of 12 months and were not yet included into the routine vaccination calendar of the Ministry of Health. Two of the remaining cases were between 1-4 years, one between 5-9 years, and two between 10-18 years of age. Nineteen (95\%) of our cases were not vaccinated, only one had a single dose of measles vaccination. These data indicate that susceptible individuals, particularly babies under 12 months without vaccination, are under serious risk at the event of an outbreak. In the event of an outbreak, an additional dose of vaccination administered at babies between 6-12 months would prevent the outbreak to expand, just like the mop-up practice performed in Istanbul in 2014. In the event of a serious increase in the number of cases in Turkey, an arrangement in the vaccination calendar with 3 doses at 9 months, 15 months, and first grade could also be taken into consideration as an option.

Fifteen (75\%) of the 20 cases in our study were males and $5(25 \%)$ were females, with a male/female ratio of $3 / 1$. The male/female ration in Metin et al.'s and Türkkan et al.'s studies were found as $1.7 / 1$ and $1 / 1.1$, respectively $(5,6)$. It is known that everyone at any age is susceptible to the disease without any sex discrimination unless there is measles immunization. All of our cases were Turkish citizens. The number of cases that had got into contact with measles patients was $5(25 \%)$, and 4 of them had got into contact at hospital. The first contact-case in our hospital was examined in the same outpatient clinic 1.5 hours after the index case with complaints like cough and fever. After having being hospitalized with a preliminary diagnosis of bronchiolitis, this contact case had rashes 6 days later, and simultaneously the diagnosis of the index case became definite. While the first contact patient with rashes was isolated, $0.4 \mathrm{~g} / \mathrm{kg}$ intravenous immunoglobulin (IVIG) was administered to the contact patients younger than 6 months and sharing the same room and measles vaccination was given to those older than 6 months without vaccination or 
with single dose vaccination. Measles was seen despite IVIG administration in a 5-month old case among this secondary contact group (Second contact case). The third contact case was taken to the room of the contact patients who were isolated by his/her mother. Our fourth contact patient was referred to our clinic due to fever without a source, rashes were noticed during presentation and was hospitalized with a preliminary diagnosis of measles. The patient's history revealed that the patient with rash wandered around the corridors of the service in the previous healthcare center where the patient was hospitalized with a preliminary diagnosis of measles. When the attack rate of the disease is considered to be $90 \%$, early suspicion, early isolation, strictly following isolation rules, and contact prophylaxis prove to be of utmost importance. Especially in endemic regions, inquiry and follow up must be carried out perfectly in epidemic periods when babies under the age of 12 months present with respiratory symptoms and fever, and in case of suspicion, the patient must be isolated and hospitalized. It was seen in two of our cases that isolation rules were not strictly followed, which emphasizes that informing the patient and next-ofkin and ensuring abidance are important parts of outbreak management.

The clinical progress of the disease can be atypical or modified, but it is not possible for the disease to progress without symptoms. Symptoms and clinical findings of our patients on presentation were fever, catarrh, cough, maculopapular rash, conjunctivitis, photophobia, and Koplik's spots (Table 1). High fever was the most definitive symptom in all of our patients and was taken as mean $39.21 \pm 0.8(38.6-41)^{\circ} \mathrm{C}$. Fever lasted for more than 5 days in three patients, and Kawasaki disease was considered for the differential diagnosis of the two patients but their acute phase negativities were found incompatible with this diagnosis. Eleven patients were in the prodromal period during presentation, they did not have rashes yet or the rashes were hardly visible. Therefore, hospitalization diagnosis of the patients was bronchiolitis in 7 (35\%) and fever without a source in 4 (20\%). During follow up, maculopapular rash was observed in all, and starting from the face and hairy skin, the rashes spread to the truncus and extremities. In two cases, the rashes were found more on the truncus rather than the face. Koplik's spots were observed in $6(30 \%)$ patients, and they were less than anticipated since they persisted for 12-72 hours and disappeared prior to exanthema (7). These were detected when Koplik's spots were specifically searched for during examination after first measles cases were diagnosed.

Leucopenia and significant lymphopenia were found in laboratory studies of the patients. It has been indicated that leucopenia, thrombocytopenia, and T-cell lymphopenia can be observed during measles infection (8). In previous studies, leucopenia and thrombocytopenia have been confirmed as $11.2-73 \%$ and $33.6-50 \%$, respectively $(9,10)$. CRP was slightly elevated in $40 \%$ of the cases. However, it was detected as 142 $\mathrm{mg} / \mathrm{dL}$ in one case with bacterial pneumonia secondary to measles and between 6-39.3 mg/dL in other cases.

The most common complications of measles in children include otitis media, bronchopneumonia, croup, and diarrhea. Acute encephalitis causing permanent brain damage is seen at a rate of $0.1 \%$. Mortality is encountered as a result of respiratory and neurologic complications at a rate of $0.1-0.3 \%$ (11). Three cases developed bronchopneumonia, one developed diarrhea and dehydratation and one developed febrile convulsion, length of hospital stay was mean 3.8 days and all were discharged with full recovery.

In a society with insufficient measles vaccination rate, experiencing outbreaks is inevitable in the presence of susceptible persons. In our country, vaccination rate is $96 \%$ and not below the immunization rate recommended by WHO (3). Therefore, measles outbreaks seen in the region are most probably due to external migration. Hence, among the 716 measles cases reported in 2018, 304 were foreign and 412 were domestic.

Increasing vaccination rates should be the primary objective in the prevention of measles outbreaks. Additionally, early suspicion, isolation preventions with early diagnosis, and rapid contact management on site will be able to ensure the decrease in disease spread.

Ethics Committe Approval: The ethical approval for this study was obtained from Health Sciences University, Diyarbakir Gazi Yasargil Training and Resarch Hospital Ethics Board (Decision number: 325, Date: 04.07.2019).

Informed Consent: Verbal and written patient consent was obtained.

Peer-review: Externally peer-reviewed.

Author Contributions: Concept - SÖD; Design - SÖD; Supervision - SÖD; Resource - SÖD; Data Collection and/or Processing - SÖD, ÖA, SM, BY; Analysis and/or Interpretation - SÖD, GK, SM; Literature Search - SÖD; Writing - SÖD; Critical Review - All of authors.

Conflict of Interest: No conflict of interest was declared by the authors.

Financial Disclosure: The authors declared that this study has received no financial support.

\section{References}

1. Gans H, Maldonado YA. Measles: clinical manifestations, diagnosis, treatment, and prevention. In: Hirsch MS, Kaplan SL (eds). UpToDate: last update 26.10.2019. www.uptodate.com/contents/measles-clinical-manifestation-diagnosis-treatment-and-prevention. (erişim 29.10.2019) [CrossRef] 
2. Richardson M, Elliman D, Maguire H, Simpson J, Nicoll A. Evidence base of incubation periods, periods of infectiousness and exclusion policies for the control of communicable diseases in schools and preschools. Pediatr Infect Dis J 2001;20:380. [CrossRef]

3. T.C. Sağlık Bakanlığı Sağlık Bilgi Sistemleri Genel Müdürlüğü. Sağlık Istatistikleri Yıllı̆̆ı 2017 Haber Bülteni, 2018. [CrossRef]

4. T.C. Sağlık Bakanlığı. Kızamık, Kızamıkçık ve Konjenital Kızamıkçık (KKS) Sürveyansı Genelgesi 2010. Available at: http:// www.saglik.gov. tr/TR, 11146/kizamik-kizamikcik-ve-konjenital-kizamikcik-kks-surveyansi-genelgesi-2010.html. Access 14.11.2019. [CrossRef]

5. Metin Ö, Tanır G, Öz FN, Kalaycıoğlu A, Yolbakan S, Tuygun N, et al. Evaluation of 44 pediatric measles cases detection in Ankara, Turkey during 2012-2013 epidemic and moleculer characterization of the viruses obtained from two cases. Mikrobiyol Bul 2014;48:256-70. [CrossRef]

6. Türkkan ÖN, Önal ZE, Sağ Ç, Akıcı N, Gürbüz T, Nuhoğlu Ç. Kızamık olgularımızın demografik özellikleri, hastalığın morbidite ve mortalitesinin değerlendirilmesi. Haydarpasa Numune Med J 2017;57:83-8. [CrossRef]
7. Zenner D, Nacul L. Predictive power of Koplik's spots for the diagnosis of measles. J Infect Dev Ctries 2012;6:271. [CrossRef]

8. Cherry JD. Measles virus. In: Cherry JD, Harrison GJ, Kaplan SL, Steinbach WJ, Hotez PJ (eds). Feigin \& Cherry's Textbook of Pediatric Infectious Disease. $7^{\text {th }}$ ed. Philadelphia: Elsevier Saunders, 2014:2373-94. [CrossRef]

9. Gershon AA. Measles virus (Rubeola). In: Bennett JE, Dolin R, Blaster MJ (eds). Mandell, Douglas and Bennet's Principles and Practice of Infectious Diseases. $8^{\text {th }}$ ed. Philadelphia: Elsevier Saunders, 2015:1967-73. [CrossRef]

10. Corbin V, Beytout J, Auclair C, chambon M, Mouly D, Chamoux A, et al. Shift of the 2009-2011 measles outbreak from children to adults: an observational review at the University Hospital of Clermont-Ferrand, France. Infection 2013;4:1157-61. [CrossRef]

11. American Academy of Pediatrics. Measles. In: Kimberlin DW, Brady MT, Jackson MA, Long SS, (eds). Red Book: 2018-2021 Report of the Committee on Infectious Diseases. $31^{\text {st }}$ ed. American Academy of Pediatrics, Itasca, IL, 2018:537-50. [CrossRef] 